\title{
Principal neuropathological and general necropsy findings in 24 renal transplant patients
}

\author{
R MORTON,* DI GRAHAM, $†$ JD BRIGGS, $\ddagger$ DNH HAMILTON§
}

From the University Department of ${ }^{*}$ Pathology, Western Infirmary, $\uparrow$ Neuropathology, Southern General
Hospital, the $\ddagger$ Renal Unit and the University Department of $\S$ Surgery, Western Infirmary, Glasgow

SUMMARY The principal neuropathological and general pathological findings in a group of 24 patients with renal transplants who died in a nine-year period at the Western Infirmary, Glasgow, are described. Opportunistic infections-bacterial, protozoal, and fungal-were the commonest causes of death. Other causes included cardiac and vascular lesions, upper gastrointestinal bleeding and neoplasia.

Immunosuppressive treatment in transplant patients is largely responsible for their susceptibility to a variety of opportunistic infections of vira!, bacterial, fungal and protozoal origin. ${ }^{1-3}$

Over the past decade considerable attention has been given to the development of neoplasia after renal and cardiac transplantation, both epithelial and lymphoid tumour having been recorded. ${ }^{4}$ It is therefore of interest to review the principal neuropathological and pathological findings at necropsy in 24 renal transplant patients.

\section{Patients and methods}

During the nine years from May 1969 to May 1978, 179 renal transplants were carried out in 160 patients. In 12 cases the donors were sibs or parents and in the remainder, transplants were from cadaver donors. There were 101 males and 59 females with an age range of 11 to $53 \mathrm{yr}$ and mean age of $31 \mathrm{yr}$. Immunosuppression consisted of oral azathioprine and prednisolone, the former in a daily dose of 50-200 mg. The prednisolone dose began at 150-200 $\mathrm{mg} /$ day and was reduced steadily to reach $20 \mathrm{mg}$ at two months and $15 \mathrm{mg}$ at three months. In addition, $1 \mathrm{~g}$ prednisolone was given intravenously at operation and thereafter up to three or four times for each acute rejection episode. Thus the number of $1 \mathrm{~g}$ doses given in the first three months could vary from 1 to $10-15$.

During this nine-year period 30 of the 160 patients died. Necropsy permission was refused in three cases. In a further three the necropsy was performed under warrant for the Procurator Fiscal because death Accepted for publication 3 June 1981. occurred within 24 hours of transplantation (two patients) or was ascribed to suicide (one patient). The remaining 24 patients (13 male and 11 female with a survival after transplantation ranging from one day to seven years) had necropsies performed in the Western Infirmary and are the subject of this report. In 12 of these 24 patients the pretransplant renal failure was due to chronic glomerulonephritis, in six chronic pyelonephritis, in three polycystic disease, in one medullary cystic disease and in the remaining two the aetiology was not known. There were no diabetic patients in this series.

The post-mortem examination reports and available paraffin-embedded material were reviewed (RM) and, where necessary, further sections were stained by haemalum and eosin, Masson's trichrome, periodic acid-Schiff (PAS), methenamine silver (for fungi) and Gram (for organisms).

A comprehensive neuropathological examination was undertaken in 17 cases (DIG). The brains were suspended in $10 \%$ formol saline for at least three weeks before dissection. Large bilateral blocks were taken from the cerebral and cerebellar hemispheres and from the brain stem in the majority of cases. They were embedded in celloidin and sections cut at $30 \mu \mathrm{m}$ were stained by the method of Nissl using cresyl violet and Woelke's modification of Heidenhain's method for myelin. Additional blocks of brain were also embedded in paraffin wax and stained with haemalum and eosin and by a variety of techniques for fungi and organisms.

\section{Results}

A summary of the principal findings at necropsy 
Table 1 Necropsy findings in 24 renal transplant patients

\begin{tabular}{|c|c|c|c|c|c|}
\hline Patient & Sex & $\begin{array}{l}\text { Age at } \\
\text { transplant } \\
(y r)\end{array}$ & $\begin{array}{l}\text { Survival } \\
\text { time }\end{array}$ & Neuropathological findings & Gencral pathological findings \\
\hline SMcG & $\mathbf{F}$ & 46 & $3 !$ months & multiple abscesses-Candida & $\begin{array}{l}\text { candidal bronchopneumonia and } \\
\text { thyroiditis }\end{array}$ \\
\hline SW & $\mathrm{F}$ & 42 & $\begin{array}{l}1 \mathrm{yr} \\
5 \text { months }\end{array}$ & multiple microglial nodules & pulmonary emboli: myocarditis, viral? \\
\hline $\mathrm{JL}$ & $\mathbf{F}$ & 37 & 1 month & multiple microabscesses? Candida & $\begin{array}{l}\text { ischaemic heart disease: } \\
\text { bronchopneumonia }\end{array}$ \\
\hline $\mathrm{CMcN}$ & $\mathbf{F}$ & 19 & $4 \mathrm{yr}$ & diffuse microgliomatosis & $\begin{array}{l}\text { disseminated lymphoma: } \\
\text { bronchopneumonia }\end{array}$ \\
\hline IT & $\mathrm{F}$ & 23 & 10 months & normal & $\begin{array}{l}\text { pericarditis with massive haemorrhagic } \\
\text { effusion }\end{array}$ \\
\hline JS & $\mathbf{M}$ & 29 & I month & normal & $\begin{array}{l}\text { oesophageal and gastric lesions with } \\
\text { bleeding: bronchopneumonia }\end{array}$ \\
\hline PR & $\mathbf{M}$ & 46 & $2 \mathrm{yr}$ & normal & miliary tuberculosis \\
\hline GW & $\mathbf{M}$ & 50 & $4 \frac{1}{2}$ months & $\begin{array}{l}\text { recent large middle cerebral artery } \\
\text { territory infarct: small old cerebral } \\
\text { infarcts: thrombosis of left internal } \\
\text { carotid artery }\end{array}$ & bronchopneumonia \\
\hline RW & $\mathbf{M}$ & 32 & $2 \mathrm{yr}$ & normal & $\begin{array}{l}\text { pulmonary Pneumocystis carin } \\
\text { infection }\end{array}$ \\
\hline RN & M & 44 & $7 \mathrm{wk}$ & normal & bronchopneumonia \\
\hline IG & $\mathrm{F}$ & 38 & 9 months & multiple microglial nodules & $\begin{array}{l}\text { orbital lymphoma: sub-phrenic } \\
\text { abscess }\end{array}$ \\
\hline HW & $\mathbf{F}$ & 21 & $2 \frac{1}{2}$ months & multiple microglial nodules & $\begin{array}{l}\text { pulmonary aspergillosis: also } \\
\text { pulmonary viral inclusions, CMV } \\
\text { pneumonitis? }\end{array}$ \\
\hline BF & $\mathbf{M}$ & 47 & $2 \mathrm{yr}$ & multiple microglial nodules & pulmonary congestion, cardiac failure \\
\hline SK & $\mathbf{F}$ & 21 & 1 month & diffuse hypoxic brain damage & $\begin{array}{l}\text { intrapulmonary haemorrhage: } \\
\text { ischaemic hepatic necrosis }\end{array}$ \\
\hline $\mathbf{S A}$ & $\mathbf{M}$ & 29 & $\begin{array}{l}4 \mathrm{yr} \\
10 \text { months }\end{array}$ & multiple staphylococcal microabscesses & multiple staphylococcal microabscesses \\
\hline $\mathbf{R} \mathbf{R}$ & $\mathbf{M}$ & 40 & 2 months & $\begin{array}{l}\text { multiple microglial nodules: boundary } \\
\text { zone infarction }\end{array}$ & $\begin{array}{l}\text { pulmonary aspergilosis: also } \\
\text { pulmonary viral inclusions. CMV } \\
\text { pneumonitis? }\end{array}$ \\
\hline $\mathbf{A P}$ & $\mathbf{M}$ & 30 & $4 \underline{d}$ months & diffuse hypoxic brain damage & $\begin{array}{l}\text { bronchopneumonia: chronic duodenal } \\
\text { ulcer: hepatic centrilobular } \\
\text { cholestasis }\end{array}$ \\
\hline CS & $\mathrm{F}$ & 38 & 4 months & no neuropathology available & $\begin{array}{l}\text { left ventricular hypertrophy, cardiac } \\
\text { dilatation, pulmonarv congestion }\end{array}$ \\
\hline EM & $\mathbf{F}$ & 31 & 1 month & no neuropathology available & $\begin{array}{l}\text { bleeding chronic gastric ulcer, } \\
\text { bilateral carcinoma in host kidneys }\end{array}$ \\
\hline MH & $\mathbf{F}$ & 23 & $\begin{array}{l}1 \mathrm{yr} \\
8 \text { months }\end{array}$ & no neuropathology available & $\begin{array}{l}\text { multiple pulmonary emboli: } \\
\text { haemorrhagic gastritis and } \\
\text { duodenitis: acute pancreatitis }\end{array}$ \\
\hline $\mathrm{OH}$ & $\mathbf{M}$ & 37 & $11 \frac{1}{2}$ months & no neuropathology available & $\begin{array}{l}\text { left ventricular hypertrophy, cardiac } \\
\text { dilatation, pulmonary congestion }\end{array}$ \\
\hline JH & $\mathbf{M}$ & 25 & $1 \frac{1}{2}$ months & no neuropathology available & $\begin{array}{l}\text { left sided Klebsiella empyema: } \\
\text { sub-diaphragmatic heamatoma }\end{array}$ \\
\hline JG & $\mathbf{M}$ & 36 & 7 months & no neuropathology available & anteroseptal myocardial infarct \\
\hline $\mathbf{J M}$ & $\mathbf{M}$ & 37 & $7 \mathrm{yr}$ & no neuropathology available & bronchopneumonia \\
\hline
\end{tabular}

together with the patients' age at transplant and survival times are given in Table 1.

Table 2 Principal neuropathological findings in 17 transplant patients

\begin{tabular}{lll}
\hline Group & Nature of lesion & $\begin{array}{l}\text { No of } \\
\text { patients }\end{array}$ \\
\hline *Inflammatory & Microabscesses-candida & 2 \\
& $\begin{array}{l}\text { Multiple microglial nodules } \\
\text { (relation to cytomegalovirus }\end{array}$ & 1 \\
& $\begin{array}{l}\text { infection?) } \\
\text { *Vascular }\end{array}$ & $\begin{array}{l}\text { Cerebral infarction } \\
\text { Diffuse hypoxic brain damage }\end{array}$ \\
Neoplastic & Diffuse microgliomatosis & 2 \\
Normal & & 5 \\
\hline
\end{tabular}

*In one patient there were both vascular and inflammatory lesions.
NEUROPATHOLOGICAL FINDINGS

The brain was examined in 17 of the 24 patients. The principal findings are given in Table 2. Abnormalities which could be grouped into inflammatory, vascular and neoplastic were found in 12 cases: in five cases the brains were normal.

\section{Inflammatory lesions}

Evidence of viral infection was seen in five patients in whom there were multiple microscopic microglial nodules scattered at random throughout the cerebral and cerebellar hemispheres (Fig. 1). There was central necrosis of many of the nodules and around some there was the occasional lymphocyte and plasma cell. Special staining techniques failed to demonstrate causative organisms and inclusion 


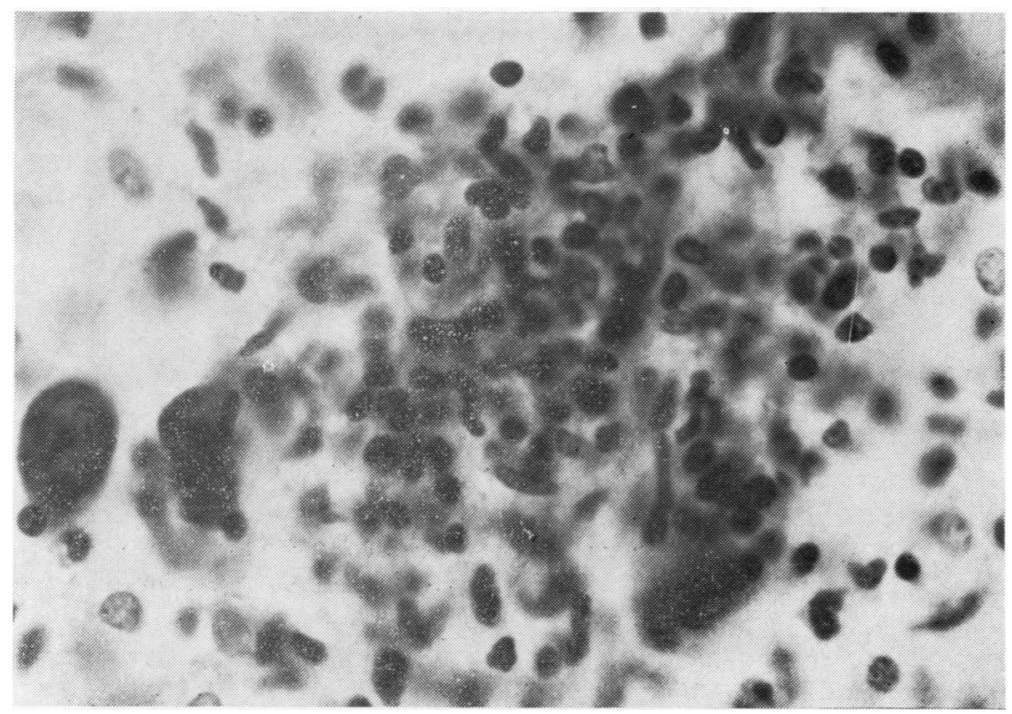

Fig. 1 Microglial nodule in cortex of patient IG.

Haemalum and eosin $\times 620$.

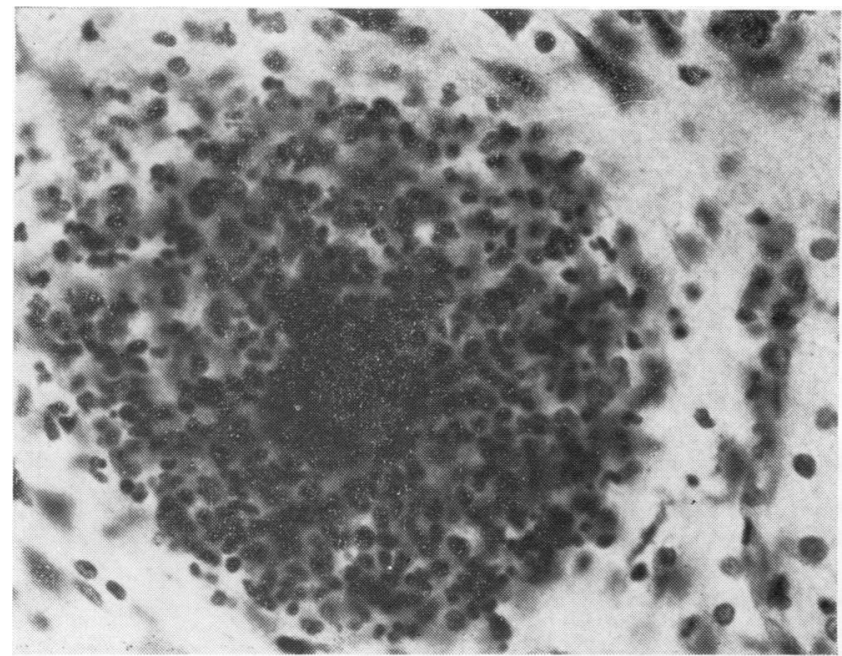

Fig. 2 Microabscess (staphylococcal) in cortex of patient AS. Haemalum and eosin $\times 390$.

bodies were not seen. These nodules were not associated with a meningoencephalitis. In one case there were multiple pyogenic microabscesses in the brain in which it was possible to identify Grampositive cocci (Fig. 2). In the remaining two patients there were cerebral abscesses due to Candida (Figs. 3 and 4): whereas the lesion was extensive in one, it consisted of a solitary small abscess in the other.

\section{Vascular lesions}

In two patients there was diffuse neuronal necrosis which was greater within sulci than at the crests of gyri and was maximal in the third, fifth and sixth layers of the parietal and occipital lobes. There was also damage in the Ammon's horns and to a variable extent in the basal ganglia including the thalami. In the cerebellum there was diffuse necrosis of Purkinje cells: the brain stem was normal. The microscopic appearances were those of ischaemic nerve cell change with and without encrustations and were characteristic of the early stages of neuronal necrosis seen after hypoxia/ischaemia. ${ }^{6}$ ?

In one patient there was ischaemic damage accentuated in the parieto-occipital sulci-that is, in the boundary zones of the cerebral hemispheres 


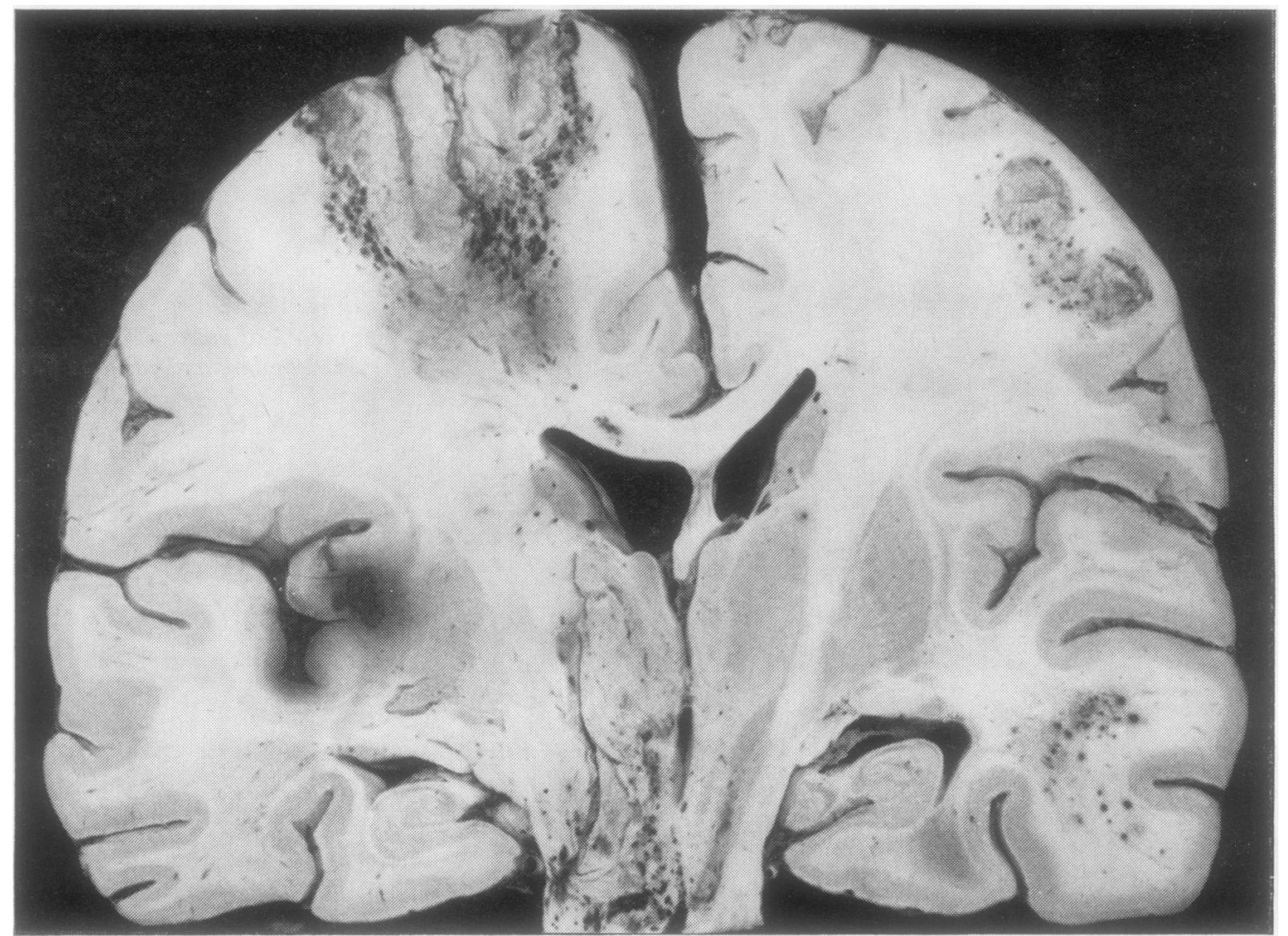

Fig. 3 Coronal section of brain of patient SMcG. There are multiple necrotic lesions in both hemispheres.

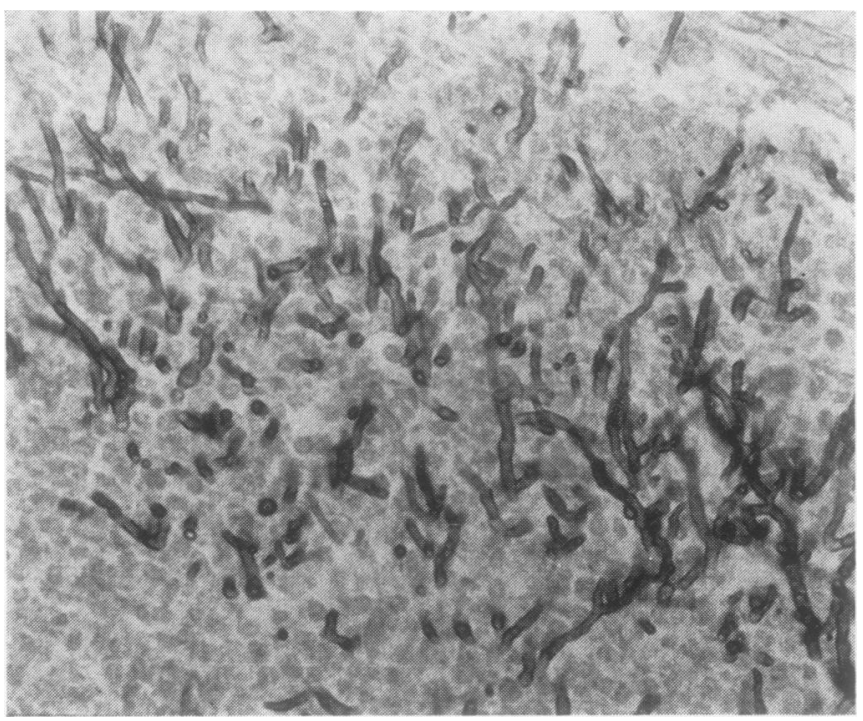

Fig. 4 Section of brain abscess: same case as Fig. 3. Hyphae ramify throughout the necrotic brain tissue. Methenamine silver $\times 390$. 
between the distributions of the anterior and middle cerebral arteries. In another patient there was extensive infarction of the left cerebral hemisphere in the distribution of the middle cerebral artery after thrombotic occlusion of the atheromatous, ipsilateral internal cartoid artery.

\section{Neoplastic lesions}

In the only patient in this category there was a perivascular infiltrate of atypical mononuclear cells throughout the cerebral hemispheres (Fig. 5). This was associated with concentric layers of reticulin, the overall appearances being those of diffuse microgliomatosis. ${ }^{8}$

In two patients (one with a large middle cerebral artery infarct and the other with multiple cerebral abscesses due to Candida) there was evidence of raised intracranial pressure. ${ }^{9}$

\section{GENERAL PATHOLOGICAL FINDINGS}

These are given in Table 3. As with the neuropathological results, the general pathological lesions encountered were mainly inflammatory, vascular or neoplastic in nature.

\section{Inflammatory lesions}

The lungs were the commonest site of infection, usually opportunistic in type. Aspergilli were responsible in two cases and Candida and Pneumocystis carinii in one each. There were two cases of bacterial pneumonia. The two patients with aspergillosis also had intranuclear viral inclusions in their lungs and multiple microglial nodules in their brains
Table 3 Principal general pathological findings in 19 transplant patients*

\begin{tabular}{ll}
\hline Pulmonary infections & \\
Fungal & \\
$\quad$ Candida & 1 \\
Aspergillus & 2 \\
Protozoal & \\
Preumocystis carinii & 1 \\
Bacterial & 2 \\
Bronchopneumonia & \\
Other infections & 1 \\
Miliary tuberculosis & 1 \\
Empyema & 1 \\
Multiple staphylococcal abscesses & \\
Cardiac and vascular lesions & 2 \\
Pulmonary emboli & 2 \\
Cardiac failure & 1 \\
Myocardial infarct & 1 \\
Haemorrhagic pericarditis & 1 \\
Carotid artery thrombosis & \\
Disseminated lymphoma & 1 \\
Orbital lymphoma & 1 \\
Renal carcinoma & 1
\end{tabular}

*In remaining five patients the proximate cause of death clinically was not mirrored by the findings at necropsy.

†In both of these patients there was also pulmonary cytomegalovirus infection.

consistent with cytomegalovirus infection (Fig. 6). In three other patients the principal findings were miliary tuberculosis, a Klebsiella empyema and multiple staphylococcal abscesses.

\section{Cardiac and vascular lesions}

In seven patients there was major pathology of the heart or large vessels. In two patients there were multiple pulmonary emboli and two had evidence of heart failure. There was one case of myocardial

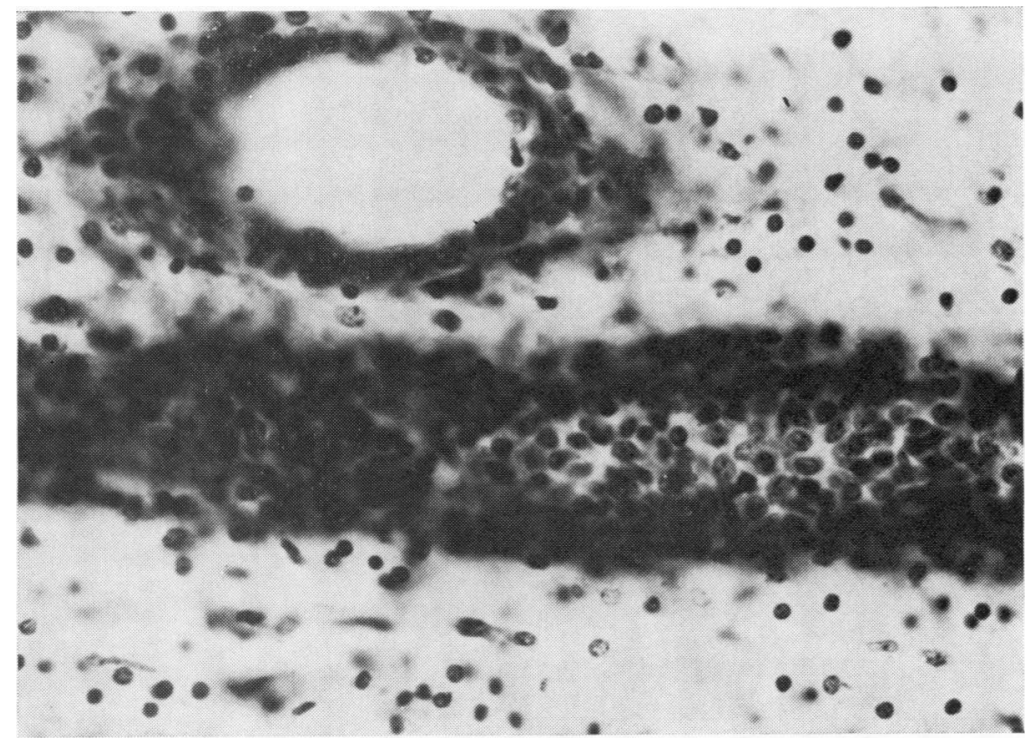

Fig. 5 Perivascular cuffing by atypical monocytes (diffuse microgliomatosis) in white matter of patient CMcN. $30 \mu \mathrm{m}$ thick celloidin section: cresyl violet $\times 390$ 


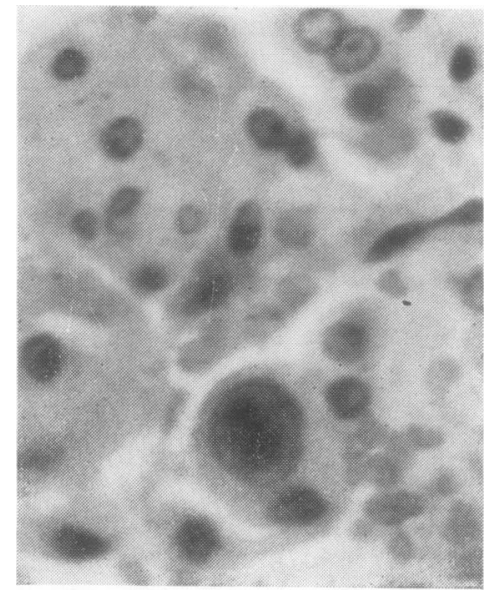

Fig. 6 Viral inclusion body (possibly cytomegalovirus) in alveolar cell of lung of patient HW. Haemalum and eosin $\times 1800$.

infarction, one of massive haemopericardium associated with pericarditis and one of carotid artery thrombosis with cerebral infarction.

\section{Gastrointestinal lesions}

Two patients had massive upper gastrointestinal bleeding, one from gastric erosions and the other from a chronic gastric ulcer.

\section{Neoplastic lesions}

Of interest was the identification of tumours which developed in three patients after transplantation. In one patient who died four years after transplantation there was a diffuse lymphoblastic lymphoma (intermediate differentiation) with involvement of the mouth, nasopharynx, stomach, liver, spleen and kidneys: the brain revealed diffuse microgliomatosis. ${ }^{1011}$ The second patient who died nine months after transplantation had a malignant lymphoma (lymphocytic intermediate differentiation) ${ }^{11}$ of the orbit (Fig. 7) and she also had microglial nodules in the brain. In the third patient who died one month after transplantation there were bilateral renal carcinomas (without metastases): these were thought to have antedated the transplant.

There were five patients in whom the proximate cause of death clinically was not mirrored by the findings at necropsy. Three of these patients $(\mathrm{JL}$, BF and SK) died of uncontrolled septicaemia, one following surgery of empyema of gall bladder, one from a shunt site infection and one from infection of the transplant wound. One patient (JM) died of uraemia due to chronic rejection while an adequate cause of death in the fifth patient (AP) was not established.

Table 4 shows the pathological findings in the transplanted kidney. In eight there were changes of severe rejection, either acute in three or chronic in five, and in addition three kidneys had been removed before death for irreversible acute rejection. In one kidney there was papillary necrosis and one monilial abscesses. Of the other 11 the appearances were normal in five or showed mild rejection in six.

Even though aseptic necrosis of bone was not looked for in every patient, there were at least three such cases in this series. In two patients there was necrosis of the femoral head and in one patient who

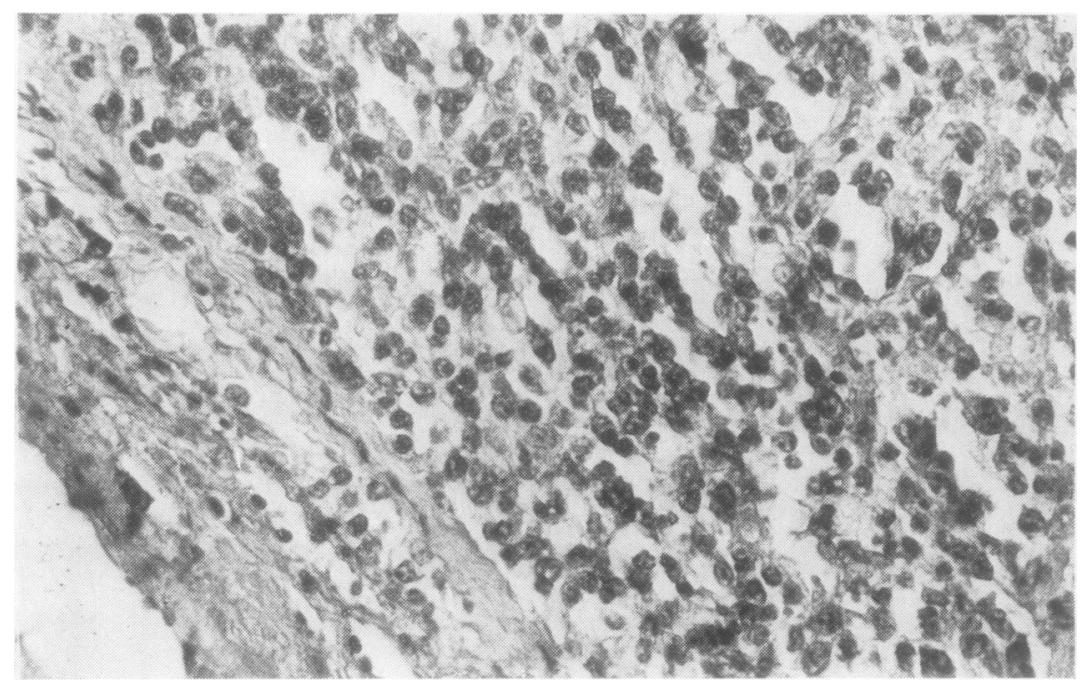

Fig. 7 Malignant lymphoma (lymphocytic intermediate differentiatio of orbit of patient IG. Haemalum and $\operatorname{cosin} \times 390$. 


\section{Table 4 Pathology of transplanted kidney}

\begin{tabular}{lc}
\hline & No of patients \\
\hline Normal & 5 \\
Acute rejection & \\
$\quad$ minimal/mild & 4 \\
$\quad$ severe & 3 \\
Chronic rejection & 2 \\
$\quad$ mild & 5 \\
advanced & \\
Miscellaneous & 1 \\
$\quad$ mapillary necrosis & 1 \\
Total & $21^{*}$
\end{tabular}

*Transplant nephrectomy carried out for irreversible acute rejection in three patients before death.

lived for seven years after transplantation there were extensive changes in the shoulders, elbows, knees and upper and lower end of the tibial shaft. ${ }^{12}$

\section{Discussion}

As in other series, ${ }^{12}$ infection was the commonest finding. Of the infections which constituted the principal necropsy findings, three were bacterial, three fungal, two aspergillosis and one monilial and one each of Pneumocystis carinii and miliary tuberculosis. Thus five of eight infections were of the so-called opportunistic type which occur in the individual with an impaired immune response. The high incidence of infection during the early period of high dose steroid treatment is also borne out by this study. Candidiasis and aspergillosis account for the majority of fungal infections. ${ }^{1-313}$ Of the three fatal fungal infections in this series two patients had pulmonary aspergillosis and one had multiple candidal abscesses. One further patient who died of bacteraemia had a single candidal microabscess in the brain. The fact that there was only a single fatal case of tuberculosis, which has in the past been a common infection in the compromised host, probably reflects more effective treatment, a falling incidence in the general population and routine prophylaxis.

Microglial nodules were the most common microscopic abnormality in the brains of the patients in the present study. Similar lesions have been noted previously. 2314 The aetiology of these nodules is uncertain but they have been ascribed to infection by either cytomegalovirus or herpes simplex virus. That the former is implicated has been shown by the finding of cytomegalovirus in the brains of one-third of patients dying after transplantation. ${ }^{214}$ Schober and Herman $^{3}$ found microglial nodules in 10 of 31 patients dying after cardiac transplantation, in seven of whom there was evidence of pulmonary cytomegalovirus. In Dorfman's series of four cases with disseminated glial nodule encephalitis, ${ }^{15}$ intranuclear inclusions consistent with cytomegalovirus were seen in two brains and the virus was isolated in three. This was in accord with epidemiological evidence that $70-90 \%$ of renal transplant patients surviving more than two months may show virological and immunological evidence of infection by cytomegalovirus. The lack of a florid inflammatory cell response to this infection is presumed to be due to an impaired immune response. Microglial nodules were seen in the brains of five of our cases, two of whom had associated intranuclear inclusions in the lungs. As in previous studies, these nodules were seen most commonly in grey matter but, unlike others, ${ }^{3}$ we have been unable to demonstrate any inclusion bodies within the CNS. It has been suggested, however, that the number of inclusion bodies seen is proportional to the amount of brain examined histologically. ${ }^{3}$ The relation between microglial nodules and infection by cytomegalovirus remains controversial and the serology of the cases in the present series does not allow adequate separation between primary and reactivated infection.

Neoplasia is another important complication of transplantation. ${ }^{3-516-18}$ Three of our 24 patients were found to have tumours at necropsy. They consisted of a disseminated lymphoma with CNS involvement by diffuse microgliomatosis, an orbital lymphoma and a bilateral renal carcinoma of the host kidneys. Each of these patients had received their first transplant and had survived $4 \mathrm{yr}$, nine months and one month after transplantation.

In a review of 438 renal transplant patients, Penn found that de novo malignancies occurred approximately 100 times more frequently in these patients than in individuals of the same age group in the general population and that the risk of this complication developing was about $6 \%^{5}$ The commonest epithelial tumours were carcinoma of the skin and lips $(40 \%)$ and cervix (8\%). Malignant lymphoid neoplasms occurred in 103 patients $(22 \%)$. Penn also noted that the mean interval between transplantation and development of the neoplasm was 34 months although the possibility that some of the tumours were present at the time of transplantation could not be completely ruled out.

Among 6297 patients reported to a kidney transplant registry, the risk of developing lymphoma was about 35 times higher than age and sex matched controls and was due almost entirely to "reticulum cell sarcoma" which was 350 times greater than expected. ${ }^{17}$ The lymphomas in transplant patients are unusual since there is a marked tendency (in about $50 \%$ of cases) to involve the CNS.417 This contrasts with the relative infrequency with which 
the CNS is involved in patients who have a malignant lymphoma and who have not been transplanted. The excess risk of developing a lymphoma appeared within a year of transplantation and remained at the same high level for the five or more years of followup. ${ }^{17}$ Hoover and Fraumeni ${ }^{17}$ found an apparent relation between the development of a lymphoma and the recipients' renal disease, attributed mainly to an increased risk in the few patients with polycystic kidneys though this association has not been confirmed subsequently. ${ }^{518}$ None of the patients in this series who were transplanted for polycystic kidney disease developed a lymphoma.

Our patient with lymphoma confined to the orbit is unusual, the association with renal transplantation not having been reported previously. Histologically proven "primary" intraocular lymphomas are uncommon ${ }^{19} 20$ but have been described in association with "reticulum cell sarcoma" of the brain.20

A likely mechanism underlying the increased incidence of malignant lymphoma following transplantation is impairment of the immunological surveillance system. This impairment has usually been blamed mainly on the use of immunosuppressive drugs although a recent collaborative study did not provide clear evidence of an increased incidence of cancer in patients treated with these drugs. ${ }^{18}$ Uraemia itself depresses cell-mediated immunity21 and the relevance of this to neoplasia is supported by the finding of an increased incidence of neoplasia in uraemic patients who have not received a renal transplant. ${ }^{22}$

Other possible mechanisms in the development of neoplasia include the effects of repeated antigenic stimulation from the transplanted kidney and the activation of an oncogenic virus. ${ }^{23}$ With regard to the latter hypothesis, infection by viruses of the herpes family are common in transplant recipients ${ }^{16}$ and two human strains belonging to this group, Epstein-Barr and herpes hominis $\mathrm{H}$ viruses have been found to be commonly associated with Burkitt's lymphoma and carcinoma of the uterine cervix respectively. That there may indeed be a link between selective immunodeficiency to the EpsteinBarr virus and the development of lymphoma following clinical infectious mononucleosis has been suggested recently. 102425

It is of interest to note that the histological appearances of the CNS malignant lymphoma described by Pattengale et $a^{25}$ in a case of selective immunodeficiency to the Epstein-Barr virus is similar to the microscopic description of microgliomatosis. ${ }^{826}$ The possibility therefore exists that at least some of the lymphomas in transplant patients pass through a stage in which they are not tumours at all but are an atypical inflammatory cell response-that is, polyclonal B cell activation to a viral agent. ${ }^{27}$ In support of this is the demonstration by immunohistochemical methods that the extracranial lymphoma in patient $(\mathrm{CMcN})$ is monoclonal for $\boldsymbol{\kappa}$ light chains whilst the diffuse microgliomatosis in her CNS is polyclonal. The nervous system lesion in this patient is therefore not neoplastic but inflammatory. It therefore seems likely that other examples of diffuse microgliomatosis, particularly in patients after transplantation, represent an atypical inflammatory cell response. If, however, the cellular infiltrate is indeed proved to be neoplastic in other cases, then the possibility exists that the lesion might have been induced by an oncogenic virus.

The occurrence of a clear cell carcinoma in the host kidneys of one patient (EM) probably reflects the increased incidence of tumours which has been reported in kidneys which are contracted due to long standing glomerulonephritis. ${ }^{28} 29$ Both cystic change and carcinoma have been found in such kidneys although the mechanism is still not understood. ${ }^{28}{ }^{29}$ The mechanisms involved in these situations are clearly different from those when tumour is accidentally transplanted from donor to recipient. ${ }^{30} 31$

Our finding that cardiac and vascular lesions come next to infection as a cause of death reflects general experience. A number of predisposing factors have either been identified or suggested. In renal failure hypertension is common as is hyperlipidaemia. The predisposition to cardiac failure is added to by the anaemia which is a constant feature in renal failure. Following transplantation, polycythaemia may occur with a predisposition to thromboembolic disease. Finally, renal failure predisposes to pericarditis and this was the likely mechanism in the patient (IT) who had recently returned to dialysis following transplant nephrectomy.

The final two principal necropsy findings in our study consisted of a chronic gastric ulcer and gastric erosions, both of which had been associated with massive bleeding. Renal failure patients have an increased incidence of peptic ulcer to which a high gastric acid secretion may contribute. ${ }^{32}$ The addition of steroid treatment after transplantation inevitably leads to a high mortality from the complications of peptic ulcer. ${ }^{33} 34$

This study illustrates the fatal complications most frequently encountered after renal transplantation. There are encouraging signs that the most common, namely infection, can be considerably diminished by the use of a low dose steroid regimen (unpublished observations) which has already been shown to be compatible with good graft survival. ${ }^{35}$ Also more effective antiviral and antifungal drugs 
are being introduced. The use of low dose steroids should also diminish considerably the incidence of peptic ulceration and its complications. The likelihood of progress in the immediate future in lowering the incidence of the vascular and neoplastic complications of renal failure is much less.

We gratefully acknowledge helpful advice and comments from Professor JH Adams, Professor WR Lee, Dr FD Lee and Dr ME Catto. We are also grateful to Dr I Brown for help with the immunohistochemistry, to the Department of Medical Illustration, Southern General Hospital for photographic assistance and to Mrs $\mathrm{K}$ McCallum and Miss $M$ McGovern for secretarial assistance.

\section{References}

${ }^{1}$ Rifkind D, Marchioro TL, Waddell WR, Starzl TE. Infectious disease associated with renal homotransplantation. 1. Incidence, types and predisposing factor. JAMA 1964;189:397-407.

${ }^{2}$ Schneck SA. Neurology and neuropathology of immunosuppressive therapy and acquired immunological deficiency. Assoc Res Nerv Ment Dis 1971;XLIX: 293-304.

${ }^{3}$ Schober R, Herman MM. Neuropathology of cardiac transplantation. Survey of 31 cases. Lancet 1973 ; i :962-7.

4 Schneck SA, Penn I. De-novo brain tumours in renaltransplant recipients. Lancet 1971 ; i :983-6.

${ }^{5}$ Penn I. Malignancies associated with renal transplantation. Urology 1977;suppl X: 57-63.

- Brierley JB. Cerebral hypoxia. In: Blackwood W, Corsellis JAN, eds. Greenfield's neuropathology 3rd ed. London: Arnold, 1976:43-86.

7 Graham DI. Pathology of hypoxic brain damage in man. In: Morson BC, ed. Hypoxia and Ischaemia. J Clin Pathol 1977;30, suppl 11:170-80.

${ }^{8}$ Adams JH. The classification of microgliomatosis with particular reference to diffuse microgliomatosis. Acta Neuropathol (Berl) 1975 ;suppl vi;119-23.

- Adams JH, Graham DI. The relationship between ventricular fluid pressure and the neuropathology of raised intracranial pressure. Neuropathol Appl Neurobiol 1976;2:323-32.

10 Briggs JD, Hamilton DNH, MacSween RNM, Pennington TH. Infectious mononucleosis, herpes simplex infection, and diffuse lymphoma in a renal transplant recipient. Transplantation 1978;25:227-8.

11 Bennett MH, Farrer-Brown G, Henry K, Jellife AM. Classification of non-Hodgkin's lymphomas. Lancet 1974 ;ii:405-6.

12 Catto M. Pathology of aseptic bone necrosis. In: Davidson JK, ed. Aseptic necrosis of bone. Amsterdam: Excerpta Medica, 1976:3-100.

${ }^{13}$ Rifkind D, Marchioro TL, Schneck SA, Hill RB. Systematic fungal infections complicating renal transplantation and immunosuppressive therapy. Am J Med 1967; $43: 28-38$.

${ }^{14}$ Schneck SA. Neuropathological features of human organ transplantation 1. Probable cytomegalovirus infection. J Neuropathol Exp Neurol 1965;24:415-29.

15 Dorman LJ. Cytomegalovirus encephalitis in adults. Neurology 1973;23:136-44.

16 Penn I, Starzl TE. Malignant tumors arising de novo in immunosuppressed organ transplant recipients. Trans- plantation 1972;14:407-17.

17 Hoover R, Fraumeni JF. Risk of cancer in renal-transplant recipients. Lancet 1973 ;ii:55-7.

${ }^{18}$ Kinlen LJ, Sheil AGR, Peto J, Doll R. Collaborative United Kingdom-Australasian study of cancer in patients treated with immunosuppressive drugs. $\mathrm{Br} \mathrm{Med} J$ 1979 ;iv:1461-6.

19 Michels RG, Knox DL, Erozan YS, Green WR. Intraocular reticulum cell sarcoma. Diagnosis by pars plana vitrectomy. Arch Ophthalmol 1975;93:1331-5.

${ }^{20}$ Kennerdell JS, Johnson BL, Wisotzkey HM. Vitreous cellular reation: associated with reticulum cell sarcoma of brain. Arch Ophthalmol 1975;93:1341-5.

${ }^{21}$ Boulton-Jones JM, Vick R, Cameron JS, Black PJ. Immune responses in uraemia. Clin Nephrol 1973; 1:351-60.

${ }^{22}$ Matas AJ, Simmons RL, Kjellstrand CM, Buselmeir TJ, Johnson TL, Najarian JS. Increased incidence of malignancy in uraemic patients and its significance to transplantation. Transplant Proc 1977;9:1137-40.

${ }^{23}$ Rubinstein LJ, Herman MM. Recent advances in human neuro-oncology. In: Smith WT, Cavanagh JB, eds. Recent Advances in Neuropathology, Vol 1. Edinburgh: Churchill-Livingstone, 1979;179-223.

${ }^{24}$ Purtilo DT, Yang JPS, Allegra S, deFlorio D, Hutt LM, Soltani M, Vawter G. Hematopathology and pathogenesis of the X-linked recessive lymphoproliferative syndrome. Am J Med 1977;62:225-33.

${ }^{25}$ Pattengale PK, Taylor CR, Panke T, et al. Selective immunodeficiency and malignant lymphoma of the central nervous system. Possible relationship to the Epstein-Barr virus Acta Neuropathol (Berl) 1979;48: 165-9.

${ }^{26}$ Russell DS, Rubinstein LJ. Pathology of tumours in the nervous system 4th ed. London: Arnold, 1977; 101-15.

27 Purtilo DT. Epstein-Barr-virus-induced oncogenesis in immune-deficient individuals. Lancet 1980;i:300-3.

${ }^{28}$ Dunhill MS, Millard PR, Oliver D. Acquired cystic disease of the kidneys: a hazard of long-term intermittent maintenance haemodialysis. J Clin Pathol 1977; 30:868-77.

${ }^{29}$ Ishakawa I, Saito Y, Ounouchi Z, et al. Development of acquired cystic disease and adenocarcinoma of the kidney in glomerulonephritic chronic haemodialysis patients. Clin Nephrol 1980;14:1-6.

${ }^{30}$ Forbes GB, Goggin MJ, Dische FE, et al. Accidental transplantation of bronchial carcinoma from a cadaver donor to two recipients of renal allografts. J Clin Pathol $1981 ; 34: 109-15$.

${ }^{31}$ Harvey L, Fox M. Transferral of malignancy as a complication of organ transplantation: an insuperable problem? J Clin Pathol 1981 ;34:116-22.

32 Ventkateswaran PS, Jeffers A, Hocken AG. Gastric acid secretion in chronic renal failure. $\mathrm{Br}$ Med J 1972;iv: 22-3.

${ }^{33}$ Penn I, Groth CG, Brettschneider L, Martin AJ, Marchioro TL, Starzl TE. Surgically correctable intra-abdominal complications before and after renal homotransplantation. Ann Surg 1968;168:865-70.

${ }^{34}$ Hadjiyannakis EJ, Evans DE, Smellie WAB, Calne RY. Gastrointestinal complications after renal transplantation. Lancet 1971 ;ii:781-5.

${ }^{35}$ McGeown MG, Douglas JF, Brown WA, et al. Low dose steroid from the day following renal transplantation. Proc Eur Dial Transplant Assoc 1979;16:395-9.

Requests for reprints to: Dr R Morton, Department of Pathology, Southern General Hospital, Glasgow, G51 4TF. 